\title{
Some Martial Motifs as Embedded Into Turkish Traditions
}

\author{
Sinan Çaya ${ }^{a}$
}

\begin{abstract}
Turkish people traditionally make good soldiers. In the Republican Turkey, the draft [conscript service system is the valid application whereby privates (rankless plain soldiers)] are recruited from among healthy and young male citizens, for a specific term specified by law. Such draftees (conscrips) constitute the backbone of the military man-power. Their numbers attain figures much bigger than the numbers of rank-carrying personnel, namely the petty-officers and officers (generals are very few in number). It is a widely known fact that military life, all over the world, is indeed tough and this is especially true for the rank-and-file, who constitute the lowest levels or the base of the involved hierarchical pyramide. When conscripted for the service, the crushing majority of the young lads go to serve willingly (see Figure 1) and proudly and even with pleasure (see Figure 2). Those who do not readily render themselves to the armed forces are only a small minority. The reason for that is the high prestige enjoyed by all military personnel within the society. Deeply-rooted historical and cultural interpretations come into play, to make us understand the significance and even the sacredness of the armed service. Indeed, merely a collection of songs and ballads praising military themes, justifies the high value of soldierly ways for Turkisp people.
\end{abstract}

\section{Keywords}

Soldier, conscript, army, military

There is no doubt that Turks make good soldiers. The population loves their military. Foreign observers underline the economical hardships of Turkey in an attempt to explain how come the Turkish soldier complies with the harsh military conditions.

Service personnel were adequately fed and clothed and, although life in the barracks was often austere and demanding, most conscripts lived as well as or better than they did in the villages from which they came. Given the uncertainties of an economy, suffering from high inflation and severe unemployment, few conscripts tried to dodge or defer their required period of active service. Most were said to look forward to their active duty, regarding it as an all too brief respite from the problems they faced as civilians. (Nelson and Kaplan 1979: 274)

\section{A TRADITIONALLY MARTIAL NATION}

Though the above arguments cannot be knocked down altogether; the concept of national character must also be given credit. Indeed, the same authors do admit this very same national character, when it comes to martial values.

The historical combat record of the Turkish soldier was

aIstanbul University, Turkey

\section{Correspondent Author:}

Sinan Çaya, Instructor of Social Graduate Elective Courses at Istanbul University, Institute of Marine Administration and Sciences, Istanbul, Turkey

E-mail: sinan.caya@gmail.com 
legendary, as the early Ottoman period, the battle of Gallipoli during World War I, the War of Independance, and the army's performance in Konea testified. Strong, tough, and fatalistic, he has shown an unusual ability and willingness to accommodate to privation. The combat abilities of the Turkish sailor and airman also have been noteworthy in the past. (In 1950, Turkey sent) a brigade of 4,500 army troops to serve under the United Nations Command in Korea, assisting American, South Korean, and other forces in the action against the invading armies of North Korea and China. In the ensuing three years of combat, the Turkish unit earned a good reputation for its exploits on the battlefield. The brigade's courage and fierce combat ability resulted in the highest casualty rate of any United Nation element engaged in the fighting. (Nelson and Kaplan 1979: 252, 259)

\section{THE STILL UNRELENTING DRAFT SYSTEM}

The currently valid Draft System (Conscript System) in the Republican Turkey has its roots in the late Ottoman $^{1}$ times. All healthy males are drafted to mandatory service at the age of $20^{2}$. Being a student is a ground for postponing the service until a certain age limit. Nowadays, only a minimum of a four-year-long higher education grants the individual either a short service (six months) or a sub-lieutenant officer's rank, which comprises 12 months, schooling included.

Until 1960s, re-engaged specialized second order corporals and first order corporals (uzatmalı onbaşı and çavuş) used to work for the gendarmerie. They were conscripted men who, upon completion of the service made their way into the gendarmerie; staying there and getting monthly salaries. Recently, the system is re-activated for all services: In addition to those who stay immediately following the completion of the service, ex-privates and ex-sergeants below age 30 are admitted through physical and mental exams (The pre-requisite is a high school diploma). They are called specialized sergeants (uzman çavuş) and are the professional soldiers of the army in a sense.

The military arms are infantry, armor, artillery, engineer corps, signal, transportation, quartermaster, etc. A scholar gives us a realistic picture of the
Turkish Army as it was in 1960s:

The Turkish Army counts around half a million men. A good part of the American aid and the local budget is spent to keep this army. The obligatory service period lasts 24 months (Now, this period is successively diminished is along the course of years). Those with higher education [now at least a B.S.(A.)] degrees perform their service as reserved officers. According to the given figures: An American soldier stationed in Turkey costs 7,700 dollars per year, while a Turkish soldier costs only 240 dollars. The simple Turkish soldier, called Mehmet $^{3}$, undergoes his service in rather harsh conditions: The head closely cropped (Since 1993, a soldier is allowed to have some hair on top of his head), only one piece of clothing, a straw mattress, a mediocre nourishment (900 grams of bread and 35 grams of meat per day). But, even in those circumstances, he is very devoted to his officers and executes the given orders without even bothering to understand what motives lie beneath a given order. In actuality, this soldier is not unhappy at all, the living conditions in his own village in general being more miserable. (Kışlalı 1967: 154-155)

Indeed, the army training even today is hot and the life is hard. But it has to be like that. A military motto says: "He who does not shed his sweat on peace time, sheds his own blood in war time".

Some individuals (though very few in number) can not take all that and try to escape the present situation on the cost of crippling themselves, an act which is liable to be punished by law. The informal social sanctions are also there. Such people are despised by friends, neighbors, and relatives. It is a dreadful shame to stoop into such practices.

The fighting spirit and the unquestioning obedience of the Turkish soldier came to the attention of the modern world during the Korean War on a sheer comparable basis with many other armies.

This marvelous obedience might have been made into some legends. An outstanding Turkish infantry captain was sent to a training in the British Royal Military Academy as a prize narrated the following episode in 1994:

The British cadets once asked me whether it was a truth 
concerning the right of an officer to kill one private per year if he pleases! This awful prejudice horrified me! I replied that ours is the draft system and everybody comes to the serve, including my own brother!

An officer is responsible for the life and wellbeing of each of his enlisted men. In 1984, an officer got drowned on a military beach and the first reaction of the holiday camp/beach commandant was: "At least, it was not a private who got drowned" (An officer is responsible for his own life).

Promotion of obedience (please see Figure 3 and Figure 4) on the part of the soldier has always been a problem for many armies, including, for instance, the U.S. Army. A professor of military history, Linderman, in an effort to emulate the German Soldier, draws some comparisons: "The obedience practiced for centuries by the German Soldier had always presupposed an unshakable trust that the orders he received would be sensible orders... Baron Friedrich Wilhelm von Steuben, George Washington's (Prussian) inspector general, said of the American Soldiers he observed, "One must first explain-and then give the order... Von Steuben was not the last to discover that giving orders in the American Army was a lot less fun than in the Prussian Army" (Linderman 1990: 25-26).

\section{LATENT BESIDES MANIFEST FUNCTIONS OF THE ARMY}

Let us note that in Turkey, the army serves many peace functions as well as the execution of war missions in case of need. (Among others), the most conspicuous peace-function of the army is to provide public education for young men. In former times, illiterate recruits were first taught how to read and write in special army schools (Ali Okulu) ${ }^{4}$ before being admitted to basic training. Those special schools were abolished long ago, there being essentially no more need for them.

Other armies might have done similar educative tasks for their nations. A book written by Grigoriy describes (in a somewhat exaggerated and romantic manner) the historical process whereby the Finnish Army raised the socio-economical development level of that country.

Kışlalı (1967: 156) draws attention to the contribution of the Turkish Army to the Turkish economy, which needs expertise knowledge a lot. The army achieves this by providing technical formation ${ }^{5}$ to the personnel and the enlisted men.

Traditionally, the most enthusiastic and the quickest welcome to novelties and new applications took place in the army in Turkey. Even the massive employment of computers were taken up by the military long before the other public sectors.

It goes without saying that the first function of the armed forces is the defense of the country. At first sight, it might be philosophically absurd to think about and to prepare for a possible war, which is merely an act of killing other people, if only the so-called foe. However, a realistic vision dictates that a given country can have no real alternative for his soldiers.

As long as we all can agree on an objective reality, we can build a rational world. Ideally this can be done, but, I am afraid, not in the real world. If the world can be my dream, it can also be somebody else's dream that might impose itself onto me as a reality. In the eleventh century, Hasan Sabbah founded a sect of killers, who willingly ran to kill and be killed: the Assasins. But Hasan ibn Sabbah is not an isolated incident in history. The suicidal act of a kamikaze or a suicide-bomber works under the same psychology: an imposed, subjective concept of reality. It is when all rational argument is frustrated in this manner that the military becomes necessary. Even Einstein supported a war against Hitler. The defense of human reason is one glorious task of the military. This holds true for the Turkish military also, who have inherited Atatürk's rationalist views. (Paraphrased from Şengör 2000: 13)

It is this difficulty of the service which makes it honorable. He who successfully accomplishes this obligation is a proud man. He is now more of a man, whereas one who was exempted from duty due to 


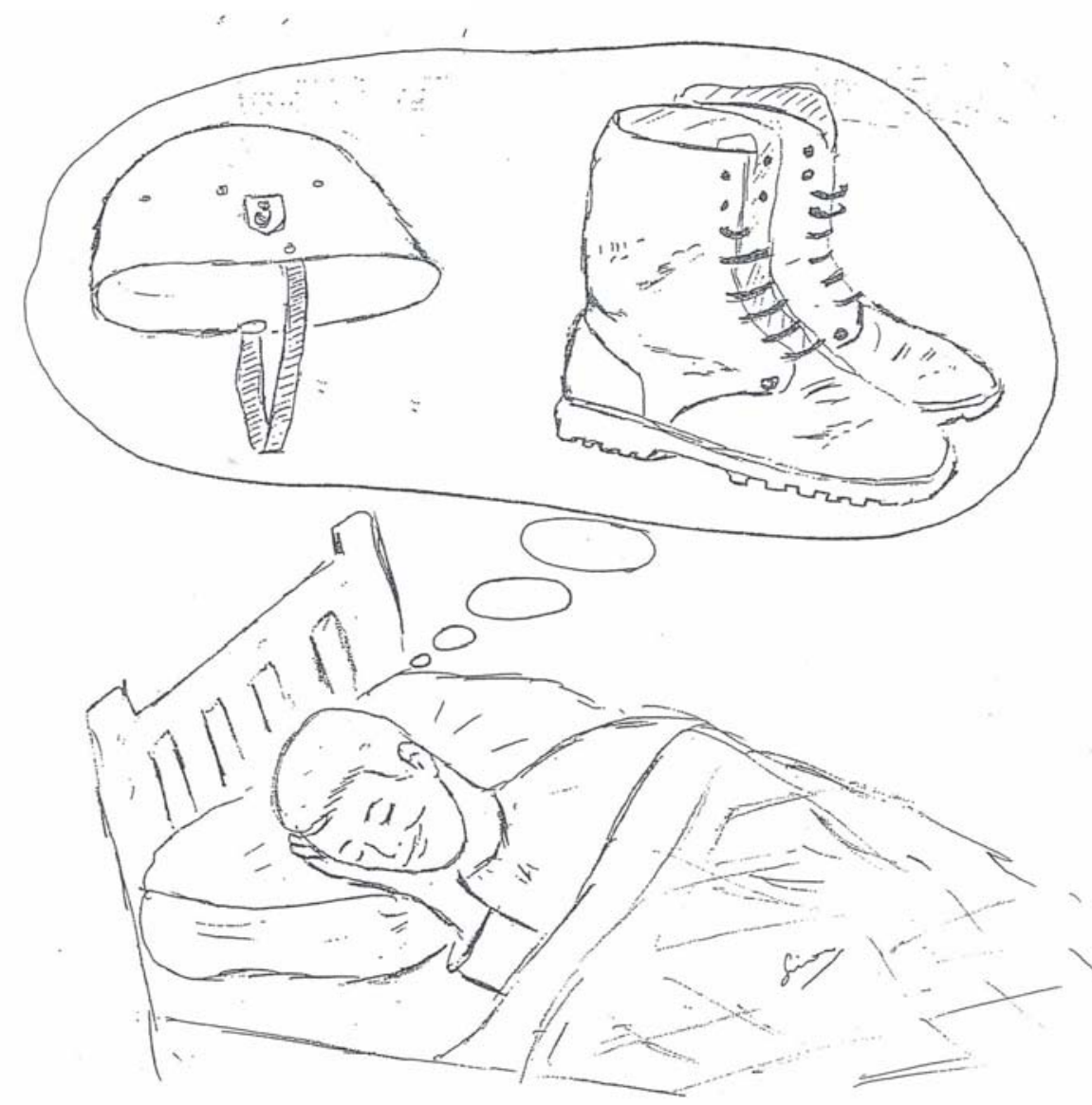

İlk yoklamadan önce Türk gencinin tatlı düşü.

Figure 1. The Happy Dream of the Young Turkish Male on the Verge of Being Conscripted. Even Though Some Fear Is Associated With the Excitement of Being a Novice-Conscript, Most Young Men Go Proudly and Even Willingly. It Is a Shame to Be Rejected by the Service, Due to Poor Health or Disability, Especially in Small Communities. Source: illustrated by the author. 


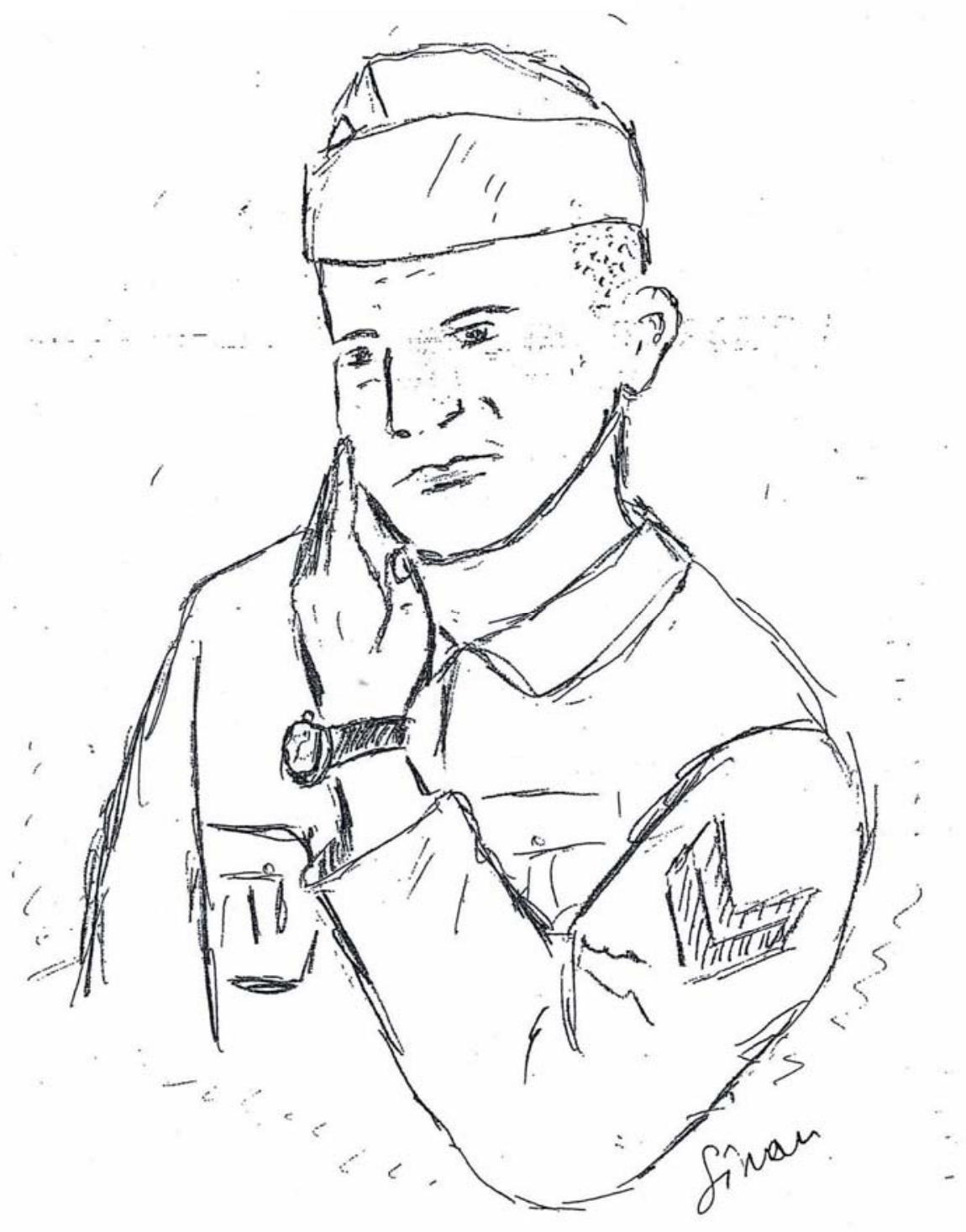

Figure 2. A Two-Stripped Senior Corporal Conscript. If Bestowed With One or Two Red Strips on His Arms in the Army, the Young Man Immediately Sends His Uniformed Photograph Home. The Rank Sticks to Him as a Life-Time Title. Up to 1960s, a Borrowed Wristwatch Used to Further Enrich the Picture. Source: illustrated by the author. 


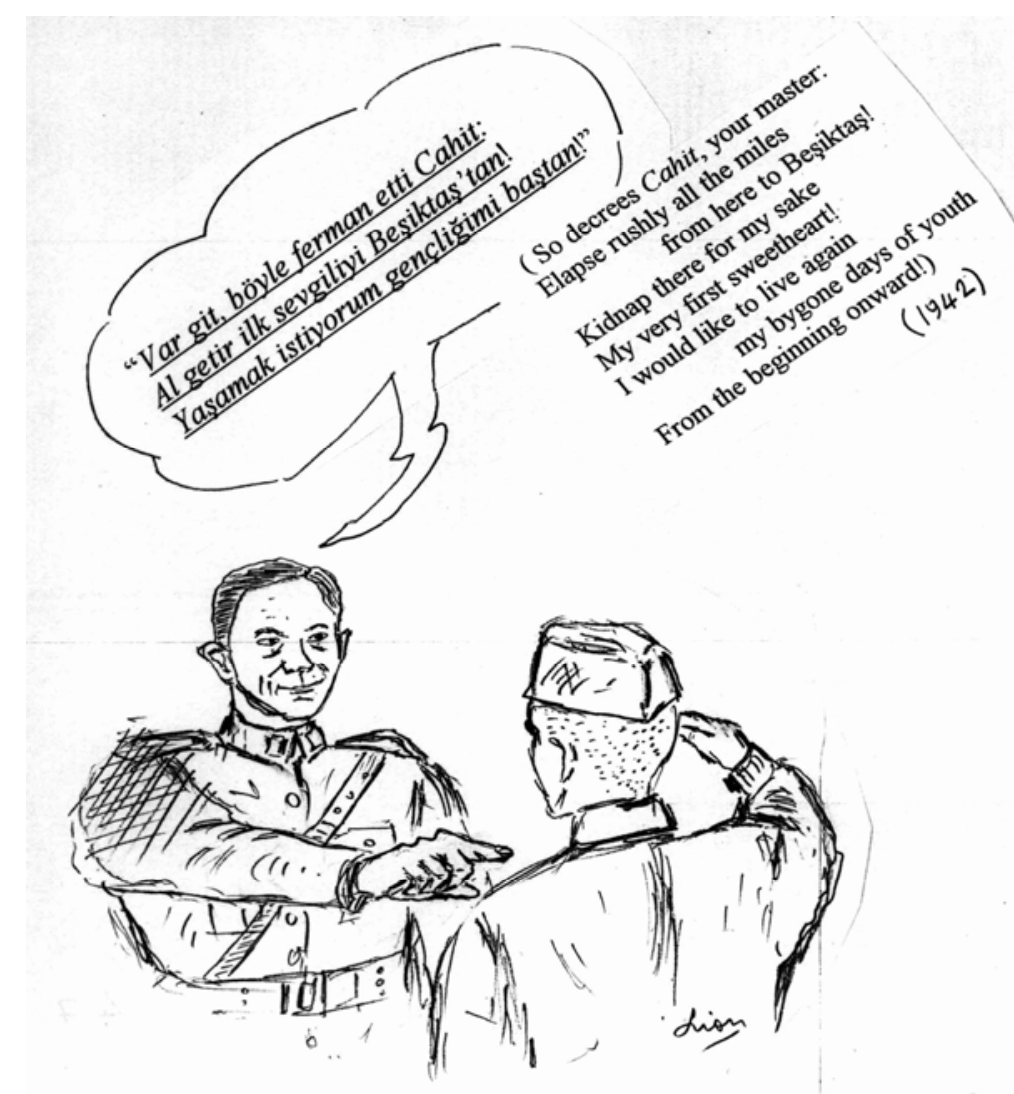

Figure 3. When Conscripted, Peasant Youths Become Loyal, Obedient, Capable Plain Soldiers in the Army. Poet Cahit Sitkı Tarancl, While He Was a Reserve-Lieutenant in Edremit in 1942, Had an Orderly From Midyat-Mardin, Named Abbas. The Poet Regarded His Naïve Soldier as the Jinn Inside Aladdin's Magic Lamp, Ready to Execute Any Issued Command. Source: illustrated by the author.

Some of his famous poems are addressed to this very soldier directly, as the following one:

\author{
"Haydi Abbas, vakit tamam; \\ Akşam diyordun işte oldu akşam \\ Kur bakalım çilingir soframızı \\ Aya haber sal çıksın bu gece \\ Görünsün şöyle gönlünce! \\ Bas kırbact sihirli seccadeye \\ Göster hükmettiğini mesafeye \\ Ve zamana" \\ (Comon Abbas, it's the right time \\ The evening time, I mean \\ Do prepare our snack! \\ Along with the drinks \\ Go notify the moon \\ It should shine as full moon in the sky tonight! \\ Whip the magic praying rug, will you? \\ Show us that, time as well as distance \\ Indeed respond to your wishes!)
}




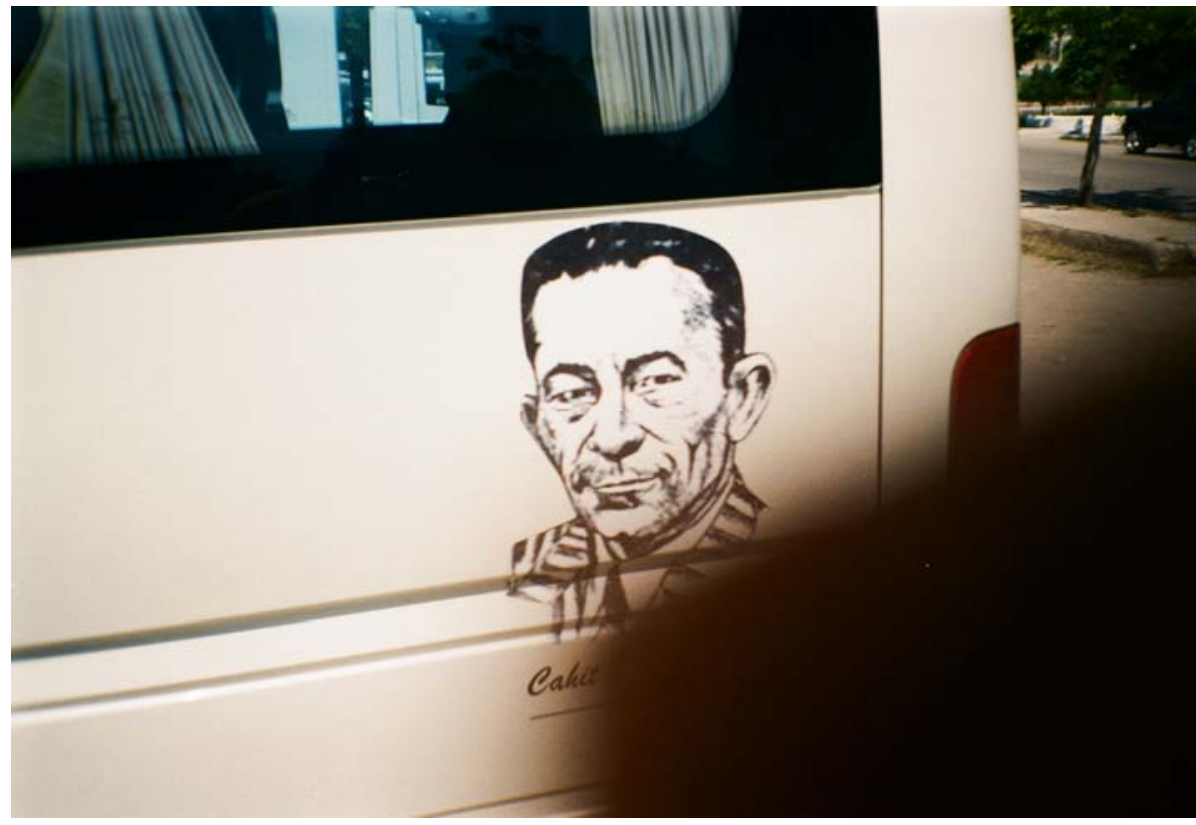

Figure 4. The Poet Pictured on a School Bus. Source: photographed by the author.

health reasons feels ashamed among ex-veterans all his life long. Similarly, in a typical village coffee-house, teen-agers who have not yet been in the army are individuals of lower social status with respect to other young men who had returned from the army.

\section{THEY DO ENJOY HIGH ESTEEM}

The army as an institution enjoys a very high prestige in the eyes of the citizens:

As the carrier of an ongoing modernizing process, the military in Turkey has a unique place. The regard and the trust of the people are directed toward the military. The reason for that respect surely goes back to the traditional army, which for almost 600 years represented the state power in the Ottoman times. The maintenance, the expansion, and even the administration of territories used to depend on the army. The instigated reforms were realized in the military-technical domain first, later followed by applications in administration and state. Those reforms were pragmatic in nature and pertained to certain concrete aims, thanks to which they could without interruption make their way into the larger society. It was the Turkish Military who, through the victory against the Greek invaders, after the war of independence from 1920 till 1923, made the formation of a nation-state tangible. Atatürk, the founder of this nation-state, came from the military just like many other leading figures of the early Republican times. The military played a certain role in the Republic too, now as the protector of the new state and the Kemalist ideals. (Şen 1986: 130)

The military might of Turkey was occasionally praised by foreigners and even regarded as a source of pride by her past or present allies, as it is reflected in a German newspaper article dated 1933. The ambassador von Papen makes a declaration, after witnessing the 10th anniversary festivities of the new republic. Though basically a politically motivated compliment, a lot of truth is there:

We the old comrades-in-arm who had fought shoulder to shoulder, know for best how devoted Turks are to nationalistic issues and what a horrible bloodshed they sacrificed through decades, in order to grant their freedom and existence. A piece of luck offered me the opportunity to be nearby that man of action (Atatürk)! And, with many comrades from the German Army, I now reflect upon the times when we had the honor to fight for the sake of a common great purpose along his side and under his 
supervision. When I got to know him, his military reputation grown out of his deeds in the Dardanelles, had already made its print in history! I saw him while he was spending his rich energy as the leader of the Palestinian-front. There he was resisting the rush of the perfectly equipped and superior-in-number English power. My last remembering of him reaches out to the day of the collapse, when we had a short talk. On that gloomy October 1918 day, he said to me: "The fate decided against us! Each of us must search for new ways, to free our folks from this awful situation. The curtain has fallen. The second act begins!". The second act is just now in the Book of History registered, as we today, rightfully celebrate the great work of the field-hero and the statesman! (Ülger 1992)

The Turkish Nation regards the armed forces as the protector of the national aspirations, as the great national school of discipline and the armed forces contribute to the economical, cultural, and social efforts of the nation... People are proud of their soldiers as the spontaneous sounds of applause coming from the admiring spectators from the sides of the avenues during parades verify. (Stüwe 1974: 127)

\section{THE CULTURE IS EMBEDDED WITH MILITARY ALLUSIONS}

The first songs sung and the first poems recited by little boys deal with the theme of "the little soldier". Many metaphors, sometimes used even by women ${ }^{6}$, derive from martial concepts. Numerous classical Turkish music works and especially folk songs (and even some recent pop-songs) make allusions to war and military. Such songs usually glorify military ways and means, while recognizing the difficulties involved, especially in the context of being separated by the beloved. The mood of the soldier as well as the mood of his close relations back home, is vividly and beautifully described in such songs. Some examples from the words of some songs are the following:

\footnotetext{
"İhtiyatlar silâh silâh çatmış yolun üstüne Nazlı yârim geli-gelivermiş sol dizin üstüne" [The (elderly) reserved soldiers had stacked their rifles on the road And that whimsical darling of mine, she has snuggled up to lie down on my left knee!]
}

"Yine yakmış yâr mektubun ucunu

Askerlikte sevdâ çekmek zor diyor"

(Here again my lover had burnt the corner of his letter!

He means that it is hard for a lover to be away, in the army)

This last song is not an anonymous ballad/folk-song; it is in the style of a classical Turkish song and was composed by a Turkish composer based on the words written by a naval officer, Bekir sttkı Erdoğan.

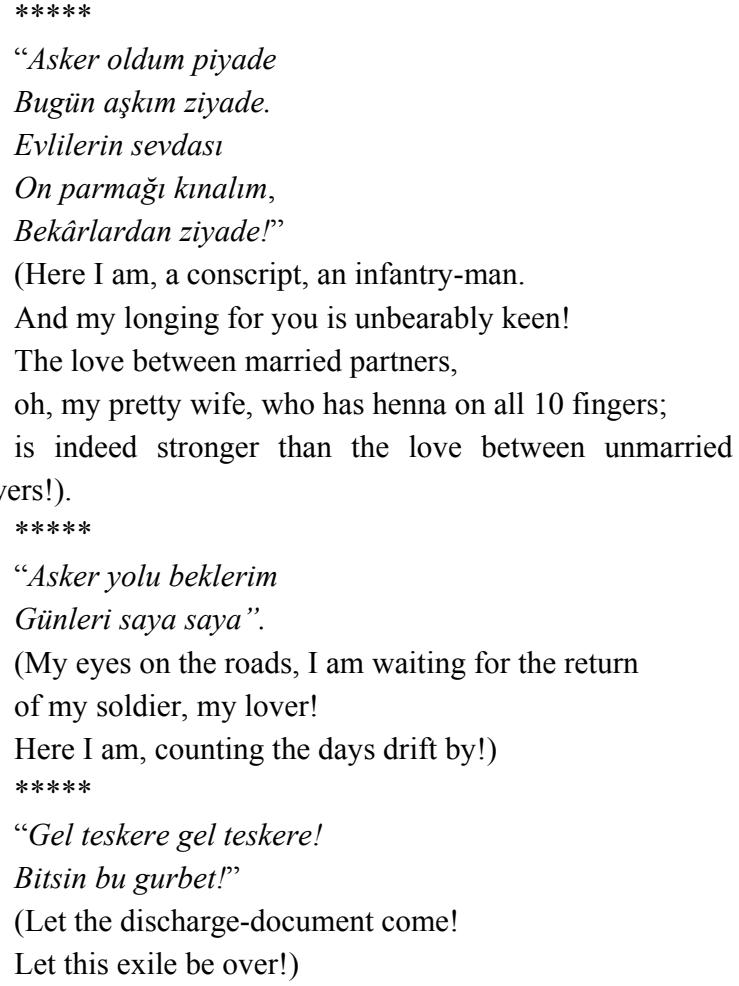

The last song was a vey popular song recited by the black Turkish female singer Esmeray in 1970s. Esmeray died on March 25, 2002, in İstanbul. Many personnel from the First Army attended the funeral of the late army-lover-celebrity. In fact, she died at the Military Medical Academy, where she had been hospitalized.

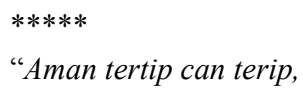


Hasrete katlan tertip!"

(Comrade-in-arm, good old sport!

Try and endure this home-sickness, just be patient!)

The last song is not an anonymous ballad/folk-song; it is a popular song composed and sung by the male singer Ersen. It was especially popular in late1980s and early 1990s.

\section{$* * * * *$}

“Burası Muş'tur; yolu yokuştur.

Giden gelmiyor, acep nedendir?".

This place is called Muş (in East Anatolia),

here the streets are steep;

[He who goes (to fight in Yemen) never returns; and why is that so?]

$$
* * * * *
$$

"Klşlalar doldu bugün.

Doldu boşaldı bugün

Gel kardeş, barışalım

Ayrılık oldu bugün!"

(The barracks are bursting with soldiers today!

Come brother, it is time for us to reconcile

Before the army service separates us!)

$* * * * *$

"Gemilerde talim var

Bahriyede yârim var"

(The battleships are making manoeuvre

And my darling man is sailing in one them!)

**

"Azizabdal dă̆ı ordugâh yeri

Bir haftallk tayın yenmiyor kuru"

(Azizabdal Mountain is

where we have our bivouac.

And it is hard, man,

to gnaw at that seven-day-old stale bread ${ }^{7}$ !)

$* * * * *$

"Yandım çavuş yandım senin elinden!

Çok sallanma kasatura da firlar belinden!"

(Oh corporal, how I fancy you!

But do not stagger, or else your bayonet

will fly off your cartridge-belt!)

$* * * * *$

"Çanakkale içinde vurdular beni

Ölmeden mezara koydular beni

Of gençliğim eyvah!"

(In the War of Dardanelles

They did shoot me!

And before I died

They did bury me!
Alas, my youth is gone!)

$* * * * *$

"Ben varmam inekliye

Yoğurdu sinekliye

Allah nasib'eylesin

Omuzu tüfekliye!"

[I will not marry a cow-keeper!

One whose yoghurt-bowl is full of flies!

Let Allah make it possible

for me to get married

To a man with a rifle on his shoulder (a military man)!]

$* * * * *$

"Kara çadır is mi tutar?

Martin tüfek pas mı tutar?

Ağlayanım anam bacım

Elin kızı yas mı tutar?"

[Will the black tent get sooty?

Will the musket get rusty?

Over my lot will cry

Only mammy and sister

Why should others' daughter (my sweetheart)

ever mourn for me?]

$* * * * *$

"Cenderme çavuşuyam [jandarma çavuşuyum]

Yol verin savuşuyam [savuşayım]

Beni çavuş sanmayın;

Kızların paşasıyam [paşasıyım]!"'

(I'm a gendarme-corporal

Make way and let me slip away!

Do not take me as a corporal

For, in the eyes of the girls;

I am no less than a pasha!)

$* * * * *$

"Ilimon ekdim daşa (limon ektim taşa)

Amanın bitmedi, kaldı kışa!

Kız ben seni alır idim

Amanın, askerlik geldi başa!"

[I did sow a lemon (sapling)

on stony ground

Oh no, the lemons did not

wholly ripen up!

Maybe they will, next winter?

You know lovely girl, I really would

have married you, I mean it!

But, my God, there they are

coscripting poor-me now for the army!]

Though the crushing majority of songs dealing with military themes do glorify martial values, some implicitly express a slight sulking attitude about the 
compulsory service, which mercilessly separates lovers. Here is the crying of a newly married woman:

"Asker bayră̆ını da burca diktiler

Küçücük yârimi de asker ettiler/

Bben doymadan o yâri de alıp gittiler oy amman!"

(They erected the military banner on a tower embrasure

They conscripted my still-a-young-boy lover, into the service

Before I got satiated with him, they took him away, alas!")

\section{CONCLUSIONS}

Turkey is a country where anything military is of utmost importance. The military is a very important instution and military ways are internalized by the people throughout ages, due to the nation's war-waging history; which was caused by collective migrations and steady hostile confrontations on the way. Today, the geo-politically important location of modern Turkey still makes it a necessity to keep strong armed forces.

\section{Notes}

1. Ottoman Janissaries and timarli sipahis were paid soldiers. But the Ottoman State in its later years had to resort to obligatory service (For instance, the nomadic Yörük tribes of the Taurus Mountains were forced to become sedentary. When men are not settled, it is not possible to grab and bring them to the army. The famous poet Dadaloğlu recited his rebellious poems on this occasion in Çukurova). Nevertheless, following the reformation in 1839, loopholes like lottery and monetary compensation instead of actual service were also used in parallel with the obligation. Non-Moslems, students of Islamic Religion, the Sultan's servants and Bilâd-ı Selâse youths (those coming from İstanbul, Bursa, and Edirne) were exempt from the service (summarized from Ayın 1994: 101-104).

2. From 1960 s till early 1980 s, the duration of the compulsory service was two complete years in the army and the air force and three years in the navy (formerly even longer in all three services). During the Second World War, conscripts were granted special permission during harvest times. In those years, even some reserves (ihtiyats: those who had completed the service but were yet younger than
45 years old) were called back and held under arms until a new order (in other words, for an unknown period of time). In 1979, while travelling to Adana by train, I met in my compartment, some theater players going for an Anatolian Tour (actress Nisa Serezli and her team). One of the actors, then a sixty-year-old-looking man, talked about his reserve years, in a poetical and fluent manner. They never knew when they would be discharged. The days went on and on. İstanbul boys like he were keen to protect their individualities against harsh sergeants. They said to them things like "We are İsanbulites, the creme of the country. In Ottoman times, we were even exempt from the service! Treat us in accordance with our nobility!" (by the author).

3. More commonly, the simple soldier is called "Mehmetçik", the suffix being a diminutive form which means imparts the meaning "little Mehmet or petit Mehmet". Even the full name Mehmet itself is an abbreviation of Mohammed, the blessed Prophet and as such is a very common name, literally loved by Turks. This title designates the common soldier, who constitutes the main pillar of the Turkish Army. The title is an historic one. Historian Reşad Ekrem Koçu, in an extract about Fahreddin (Türkkan) Pasha gives the following knowledge. The pasha instigated this title by using it regularly in daily issued orders and registering it on to the army archives. The pasha was the defender of the city of Medine against the British and their collaborators, the local forces, during the First World War. It was he who had sent some of the holy relics of the Blessed Prophet to the treasure of the Sultan in İstanbul, before the opposing forces seized the sacred city" (Erendil 2000: 28).

4. Sometimes, an illiterate conscript is assigned to a military unit. In that rare case, a special fast and practical education program is arranged for him (by the author).

5. A scholar generalizes this to all developing countries' armies: "In the industrially advanced nations, the missions of the military are usually narrowly specified. (However), the military in the less developed part of the world is more likely to assume a variety of civic functions and missions that civilians either lack the motivation, talent, and/or resources to assume" (Lang 1970: 14-15 by reference to Bobrow and a number of other authors).

6. On September 13, 2000, the female novelist Ayşe Külin was being interviewed by a critic about her latest biographical work-Füreyya. She said: "After the novel Adı Aylin, I had repented and gave up the idea of another biographical work. However, my good friend Sâra insisted upon my writing this novel. I could not resist her because she is like my army-buddy or comrade-in-arm!".

7. I listened to this beautifully touching song in 1975, from the bass-bariton voice of the late Ruhi Su, who, according to musical authorities is like the Turkish equivalent of the 
black American singer Paul Robeson in his voice and musical manners (by the author).

\section{References}

Ayın, F. 1994. "Tanzimat'ın İlanından Sonraki Askter Alma Kanunları" (Rules to Conscript After the Ottoman Reformation). Silahl Kuvvetler Dergisi (Journal of Armed Forces) 116(339).

Erendil, M. 2000. "Mehmetçik" [Little Mehmet (Turkish-Johnny)]. Silâhlı Kuvvetler Dergisi (Journal of Armed Forces) 119(365).

Grigoriy, P. 1994. Akzambaklar Ülkesi Finlandiya'da (In Finland, the Land of the White Lillies). Translated by A. H. Aytuna. İstanbul: Ink1lâp Kitabevi.

Kışlal1, A. T. 1967. Forces politiques dans la Turqouie moderne (Political Forces in Modern Turkey). Ankara: Sevinç Printing House.

Lang, K. 1970. "Military Sociology 1963-1969.” La Sociologie Contemporaine/Current Sociology 16(3). The Hague; Paris: Mouton and Co.

Linderman, G. F. 1990. "Military Leadership and the American Experience.” Military Review, April.
Nelson, H. D. and I. Kaplan, 1979. "National Security." In Turkey: A Country Study, edited by R. F. Nyrop. Washington, D.C.: The American University Publications.

Şen, F. 1986. Turkei, Land und Leute (Turkey: The Land and the People). 2nd ed. München: Verlag C.H.Beck.

Şengör, A. M. C. 2000. "Is the Military Defensible?" The Wings Magazine, March. Yeşilyurt, Istanbul: Hava Harp Okulu (Air Force College) Publication.

Stüwe, M. 1974. Türkei Heute (mit 33 Abbildungen) [Turkey Today (With 33 Illustrations)]. Wien and Düsseldorf: Econ-Verlag GmbH.

Ülger, S. E., ed. 1992. Atatürk und die Türkei in der Deutschen Presse (1910-1944) [Atatürk and Turkey in the German Media (1910-1944)]. Hückelhoven: Schulbuchverlag Anadolu.

\section{Bio}

Sinan Çaya, Ph.D., Instructor of Social Graduate Elective Courses, Institute of Marine Administration and Sciences, Istanbul University; research fields: rural sociology and peasant studies, military sociology, forensic social sciences, leadership, general education, social history, marine sociology, and marine organizational behavior. 